\title{
FÉMGÖMBHÉJ ERŐSÍTÉSÛ ALUMÍNIUM MÁTRIXÚ KOMPOZITOK GYÁRTÁSA, TULAJDONSÁGAI, FORGÁCSOLHATÓSÁGI PROBLÉMÁI
}

\section{MANUFACTURING, PROPERTIES AND CUTTING PROBLEMS OF METAL HOLLOW SPHERE REINFORCED ALUMINUM COMPOSITE}

\author{
Horváth Richárd ${ }^{1}$, Oláh Ferenc ${ }^{2}$ \\ Óbudai Egyetem, Bánki Donát Gépész és Biztonságtechnikai Mérnöki Kar, Anyag- \\ tudományi és Gyártástechnológiai Intézet Cím: 1081, Magyarország, Budapest, \\ Népszinház utca, 8.; Telefon: +36-1-666-5326 \\ 'horvath.richard@bgk.uni-obuda.hu \\ ²illogicalferi@gmail.com
}

\begin{abstract}
It is long been known that composite materials are made from two or more constituent materials. Thereby, we can create material structures with much better mechanical properties as the constituents have. This paper shows the creating process and research results of an aluminium composite reinforced with metal hollow spheres. It also includes an analysis about the problems of cutting this kind of materials.
\end{abstract}

Keywords: composite, metal hollow sphere, material properties, cutting ability, cutting problems

\section{Összefoglalás}

Régóta ismert, hogy a kompozit anyagok, két vagy több alkotóelemböl állnak össze, ez által olyan anyag szerkezetek is létrehozhatóak, melyek mechanikai tulajdonságai lényegesen jobbak, mint az alkotórészek tulajdonságai. A dolgozatban bemutatásra kerül egy eutektikus alumínium ötvözet mátrixba ágyazott vas gömbhéjakból álló társított anyag elkészítése, kutatási eredményeinek bemutatása, valamint az ilyenféle anyagok forgácsolhatósági prblémáinak elemzése.

Kulcsszavak: kompozit, fém gömb héj, anyag tulajdonság, forgácsolhatóság, forgácsolási prombléma

\section{Bevezetés}

A kompozitokat régóta használják már a különböző müszaki területeken. Az eltérö tulajdonságú fémek használata, mint kopozit anyagok fontos kutatási terület napjainkban. Ebben a munkában a szintaktikus fémhabok kutatási eredményeit (egy kiválasztott) szintaktikus fémhab gyártását és forgácsolhatósági problémáit mutatjuk be.
A szintaktikus fémhabok vizsgálata és kutatása az elmúlt 5-10 évben fokozatosan növekszik. Az alábbiakban röviden ismertetjük az alumínium-vasgömbhéj illetve az alumínium-kerámiagömbhéj eddigi kutatási eredményeit.

A 80\% GM (globomet- vasgömbhéj) és 20\% GC (globocer- kerámiagömbhéj) erősítésü, valamint GC és SLG (kisebb kerámiagömbhéj) erősítésű eutektikus alu- 
mínium ötvözet vizsgálata során mérték ezen kompozit mechanikai és tribiológiai tulajdonságait [1] [2]. Arra az eredményre jutottak, hogy a GM-GC erösítésü összetett anyag esetén a cellák sürüsége korrelált a keménységhez, szakítószilárdsághoz, és egyéb vizsgált mechanikai tulajdonságokhoz is. Nagyobb tömöttségü anyag esetén tehát jobb tulajdonságok is kaphatóak. A nyomószilárdság, folyáshatár és szerkezeti merevség növelhetö, míg a törési alakváltozás csökkenthetö a megfelelö mennyiségü és minőségü gömbhéj alkalmazásával.

Természetesen az ilyen kompozitok kopási tulajdonságai is fontosak ezért ebben a témakörben is számos kutatás történt.

A kopási vizsgálatokat is végeztek korábban ezeken az anyagokon ún. ,pin-ondisc" teszt segítségével, mely során alacsony karbon tartalmú lemezt, 0,2 m/sec-os sebességet és 0,64 MPa nyomást alkalmaztak. A súrlódási tényező (COF- coefficint of friction) a vizsgálatok során 0,45 és 0,59 között változott, de a mátrixanyag önmagában is 0,41-es értékkel rendelkezett. A legnagyobb surlódási tényező értéket az SLG és GC erősítésű kompozit mutatta, mely során az SLG arányának növelésével egyre rosszabb értékeket kaptak. A vizsgálatokat száraz és nedves koptatás mellett is elvégezték, mindkét esetben esetben a mátrixanyag önálló használata mutatta a legalacsonyabb értéket, viszont ha figyelembe vesszük, hogy a kompozitok kopó felületének csak kb. 65-68\%-a a tömbi mátrixanyag, kijelenthetjük, hogy arányaiban jobb eredményt mutat az összetett anyag. [1] [3] [4] [5].

Másik fontos kutatási területe az előbb bemutatott kompozit anyagoknak a mikroszerkezeti vizsgálataik. Ezekben a kutatásokban a kompozitok harmadik fontos összetevőjét vizsgálták, mely az átmeneti anyag (réteg) a bázis és az erősítő között. Az átmeneti anyag hatása minden kompozitnál jelentős. A Globomet héjak jelentős oldódást mutattak a mátrixanyagban, több gömb is kiszakadt, de ezeknek egy része az infiltrációs eljárás során is sérülhetett. Ezeket a károsodott sejteket a mátrixanyag kitöltötte. A Globocer héjak esetén sokkal kisebb volt ez a jelenség, de ott is tetten érhető volt. [6]

A különböző alumíniumötvözetek alkalmazása során azt is tapasztalták, hogy az átmeneti rétegekből $\mathrm{Si}$ vált ki, mely a mátrixanyagban oldódott, valamint a gömbhéjakon A12O3 tük keletkeztek. AlCu5 mátrix esetén rézkiválást találtak a héjak falán. EDS mérésekkel jó minőségü elemeloszlás térképet is készítettek. Azt is bizonyították, hogy az infiltrációs idő nincs hatással az anyag mechanikai tulajdonságaira. [7] [8] [9] [10] [11].

Vizsgálták az infiltrációs eljárást is, melyben arra jutottak, hogy kis nyomású argon is elégséges a megfelelő átjárás eléréséhez, ráadásul ebben az esetben kevesebb erősítő anyag héj szakad át. További teszteket is készítettek, melyben a nyomással szembeni ellenállóságát vizsgálták ezen speciális kompozitoknak. Tapasztalatok szerint a mátrixanyag hőkezelése nagymértékben befolyásolta a kompozit mechanikai tulajdonságait. A folyáshatár és az energiaelnyelés is növelhető $30 \%$-al a megfelelö hőkezelés hatására. [12] [13] [14].

\section{Fémgömbhéj erősítésű alumíni- um mátrixú kompozit gyátása}

$\mathrm{Az}$ általunk létrehozott kompozitnál AlSi12 eutektikus alumínium ötvözetre esett a választásunk, mint mátrix anyag és vas gömbhéjra, mint erősítő anyagra. Ennek magyarázata, hogy az eutektikus öntészeti alumínium megfelelően önthető.

A fémkompozit gyártásához infiltrációs eljárást választottunk. A gömbhéjakat egy zártszelvényből létrehozott öntőformába helyeztük, melynek a tetejét egy ráccsal lefedtük, a vasgömbhéj erösítő anyagok felúszásának elkerülése érdekében.

Az AlSi12 mátrix anyagot olvadáspont fölé melegítettük, majd ezt követően öntöt- 
forgácsolhatósági problémái

tük rá a gömbhélyakra az előmelegített öntő formában. Argon gázzal túlnyomást okozva a berendezés alján található kivezető nyilás (melyben alumíniumoxid párna található) segítségével láthatóvá vált, ha az ömledék teljesen áthatolt az erősítőszemcsék között (1. ábra).

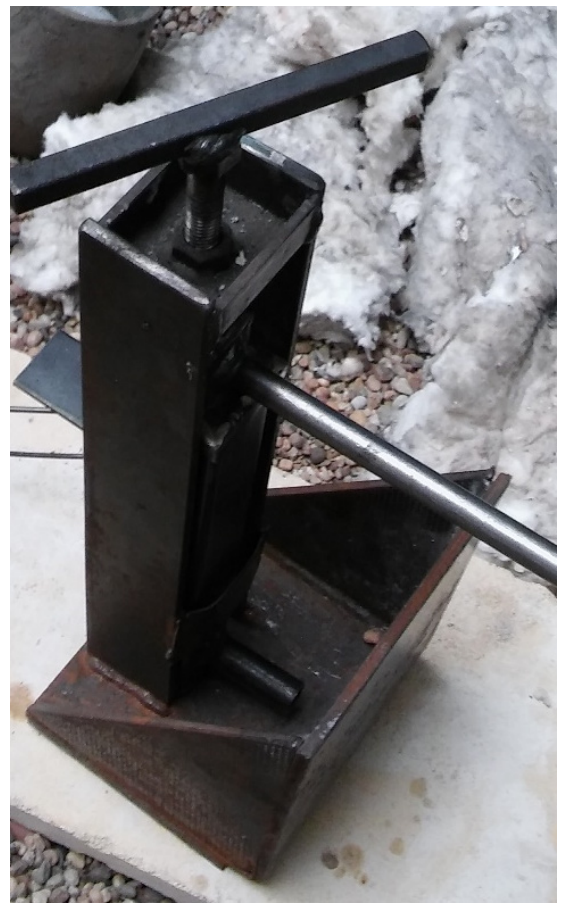

1. ábra. Infiltráló berendezés

Az általunk öntött kompozitról marással eltávolítottuk az acél öntőformát. Az elkészült fémgömbhéj erősítésű alumínium mátrixú kompozitok képét mutatja a 2. ábra.

\section{További célok}

Az általunk készített fémgömbhéj erősítésủ alumínim mátrixú kompozit forgácsolhatósági vizsgálatait végezzük el a jövőben.

$\mathrm{Az}$ ilyen anyagok forgácsolása igen nagy követelmények elé állítja a forgácsoló szerszámokat, hiszen a lágy alumínium mátrix anyag egyértelmüen $\mathrm{PCD}$ (polikristályos gyémánt) szerszámot igényelne, míg az erősítő anyag pl.: keményfém szerszám anyagot.

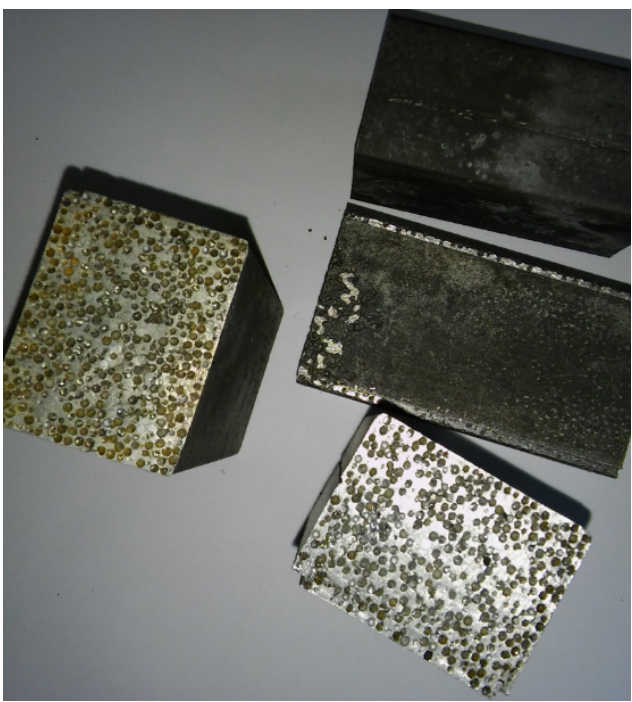

2. ábra. Elkészült fémgömbhéj erösitésü aluminim mátrixú kompozit

\section{Konklúzió}

Ebben a cikkben bemutattuk egy fémgömbhéj erősítésű alumínim mátrixú kompozit gyártását. Valamint az ilyen és efféle anyagok anyagvizsgálati kutatási eredményeit ismertettük. Az ilyen féle anyagok forgácsolással végzett esetlegesbefejező megmunkálásának kérdései még nem megoldottak. További célunk az ilyen anyagok forgácsolhatósági vizsgálatainak széleskörü elvégzése.

\section{Köszönetnyilvánítás}

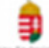

AZ EMBERI ERŐFORRÁSOK MINISZTÉRIUMA ÚNKP-16-4/I. KÓDSZÁMÚ ÚJ NEMZETI KivÁLÓSÁG PROGRAMJÁNAK TÁMOGATÁSÁVAL KÉSZÜLT

Külön köszönetünket szeretnénk kifejezni Dr. Májlinger Kornélnak a Budapesti 
Müszaki és Gazdaság Tudományi Egyetem, Anyagtudomány és Technológia Tanszék munkatársának a számunkra nyújtott segítségéért.

\section{Szakirodalmi hivatkozások}

[1] Májlinger, K., Kalácska, G., Orbulov, I. N., Zsidai, L., Bozóki, B., Keresztes, R. : Global Approach of Tribomechanical Development of Hybrid Aluminium Matrix Syntactic Foam. 2017.

[2] Májlinger, K., Orbulov, I. N.,: Hibrid szintaktikus fémhabok szilárdsági jellemzöi Bányászati és kohászati lapok 2014/1.

[3] Májlinger, K., Kalácska, G., Zsidai, L., Bozóki, B., Keresztes, R.: Tribological properties of hybrid aluminum matrix syntactic foams, Tribiology International 99, 2016, 211-223.

[4] Bozóki, B., Májlinger, K.: Alumínium mátrixú hibrid kompozitok kopási tulajdonságainak vizsgálata. XXII Nemzetközi Gépészeti Találkozó, 62-65.

[5] Májlinger, K.: Hibrid szintaktikus fémhabok kopási tulajdonságai. Bányászati és kohászati lapok 2015/1

[6] Májlinger, K., Orbulov, I. N.: Fémgömbhéj erösitésü fémhabok mikroszerkezeti tulajdonságai. XXI. Nemzetközi Gépészeti Találkozó 253-256.

[7] Májlinger, K., Orbulov, I. N.: Elemeloszlás és orientációs vizsgálat szintaktikus fémhabokon. XIX. Nemzetközi Gépészeti Találkozó, 244-247.
[8] Májlinger, K., Orbulov, I. N.: Microstructural aspects of ceramic hollow microspheres reinforced metal matrix composites. International Journal of Materials Research 104.9, 2013, 903-911.

[9] Májlinger, K., Orbulov, I. N.:Microstructure of metal-matrix composites reinforced by ceramic microballoons. Materials and technology 46 (2012) 4, 375-382.o.

[10] Májlinger, K., Orbulov, I. N.: Fémmátrixú kerámia kompozitok mikroszerkezeti tulajdonságai. Bányászati és kohászati lapok 145. évfolyam, 2012/5 53.

[11] Májlinger, K., Orbulov, I. N.: Elemental distribution and orientation analysis on metal matrix sytactic foams. 8th International Conference on Mechanical Engineering, 2012, 301-308.

[12] Szlancsik, A., Katona, B., Bobor, K., Májlinger, K., Orbulov, I.N.: Compressive behaviour of aluminium matrix syntactic foams reinforced by iron hollow spheres. Materials \& Design 83, 2015, 230-237.

[13] Szlancsik, A., Katona, B., Májlinger, K., Orbulov, I.N.:: Compressive Behavior and Microstructural Characteristics of Iron Hollow Sphere Filled Aluminum Matrix Syntactic Foams, Materials 2015, 8, 79267937; doi:10.3390/ma8115432

[14] Májlinger, K., Orbulov, I. N.: Characteristic compressive properties of hybrid metal matrix syntactic foams. Materials Science \& Engineering A 606, 2014, 248-256. 